Research Article

\title{
The Ecological Perspective of Landslides at Soils with High Clay Content in the Middle Bogowonto Watershed, Central Java, Indonesia
}

\author{
Junun Sartohadi, ${ }^{1}$ Nur Ainun Harlin Jennie Pulungan ${ }^{(D,},{ }^{1,2}$ Makruf Nurudin, ${ }^{1}$ \\ and Wahyudi Wahyudi ${ }^{3}$ \\ ${ }^{1}$ Department of Soil Science, Faculty of Agriculture, Universitas Gadjah Mada, Yogyakarta, Indonesia \\ ${ }^{2}$ Institute of Geography, University of Innsbruck, Innsbruck 6020, Austria \\ ${ }^{3}$ Department of Physics, Faculty of Natural Science, Universitas Gadjah Mada, Yogyakarta, Indonesia
}

Correspondence should be addressed to Nur Ainun Harlin Jennie Pulungan; ainungeo@gmail.com

Received 10 January 2018; Revised 10 April 2018; Accepted 11 April 2018; Published 27 May 2018

Academic Editor: Marco Trevisan

Copyright (C) 2018 Junun Sartohadi et al. This is an open access article distributed under the Creative Commons Attribution License, which permits unrestricted use, distribution, and reproduction in any medium, provided the original work is properly cited.

\begin{abstract}
The clay layers at hilly regions in the study area were very thick. The presence of very thick clay caused several difficulties in terms of environmental management, particularly in reducing georisk due to landslide. However, initial observations proved that areas of active landslides had better vegetation cover. The objective of this study was to find out ecological roles of landslides in livelihood in the Middle Bogowonto Watershed. The ecological roles of landslide were examined through field empirical evidences. Texture, bulk density, permeability, structure, and index plasticity were conducted for analyses of soil physical properties. Stepwise interpretation was made using $1: 100,000-1: 25,000$ Indonesian topographic maps and remote sensing images of $30 \mathrm{~m}-<10 \mathrm{~m}$ spatial resolution. The results showed that landslides formed three landform zones: residual, erosional, and depositional zones. The area that did not slid, the residual zone, had massive soil structure and very hard consistency. Crops cultivated in this zone did not grow well. In the areas of active landslide, the environmental conditions seemed to be more favorable for living creatures. The landslides resulted in depositional zones with gentle slopes $\left(4^{\circ}\right.$ to $\left.15^{\circ}\right)$, higher water availability, and easier soil management. The landslides also acted as the rearrangement process of landforms for better living environment.
\end{abstract}

\section{Introduction}

Landslides were the natural geohazard that widely occurred throughout the world. Many studies of landslides showed that they were destructive geohazard [1], caused loss of hundreds of lives and damage of infrastructures $[1,2,3]$. The behavior of landslides was mostly influenced by fluctuating water content and stresses in the unsaturated zone $[4,5]$. One of the stresses in the unsaturated zone resulted from soil characteristics such as clay content [6].

Clay becomes the potential slip zone in an outcrop causing landslides. Clay had characteristics of swelling, sensitive to humidity, and hydrous [7]. The small initial slip of clay might trigger large landslides that covered huge area [8]. The composition of landslide slip zone was crucial in understanding the mechanism of land sliding [9]. The abundance of clays in landslide body had significant effect on the mechanical properties of slip zone $[10,11]$. The study of Wen and Aydin [12] stated that the slip zone of landslide was the natural shear zone resulting from different stress disseminated through different lithologies.

The presence of clay in the hilly region is strongly attributed to landslides. Given that topography of the hilly region was complicated, clay played an important role in provoking slope failure to result in landslides [13]. The study of Wang et al. [14] assumed that if distribution of clay in subsurface was established, the potential damages caused by landslides could be better mitigated. In fact, landslide related to clay not only has significant influence on surface geomorphology but also on environmental problems.

Middle Bogowonto Watershed was chosen as the study area since it presented a good overview of the landslide 


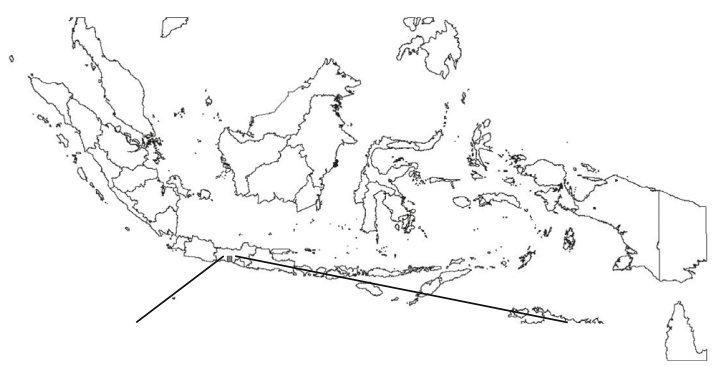

(a)

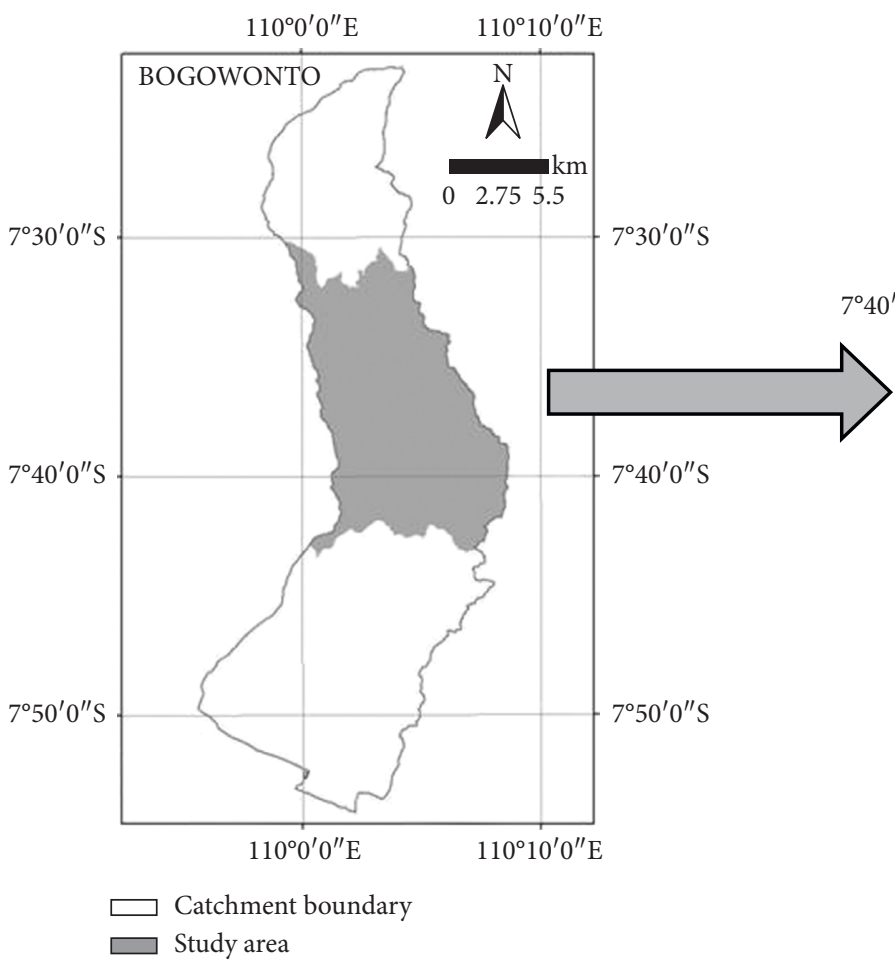

(b)

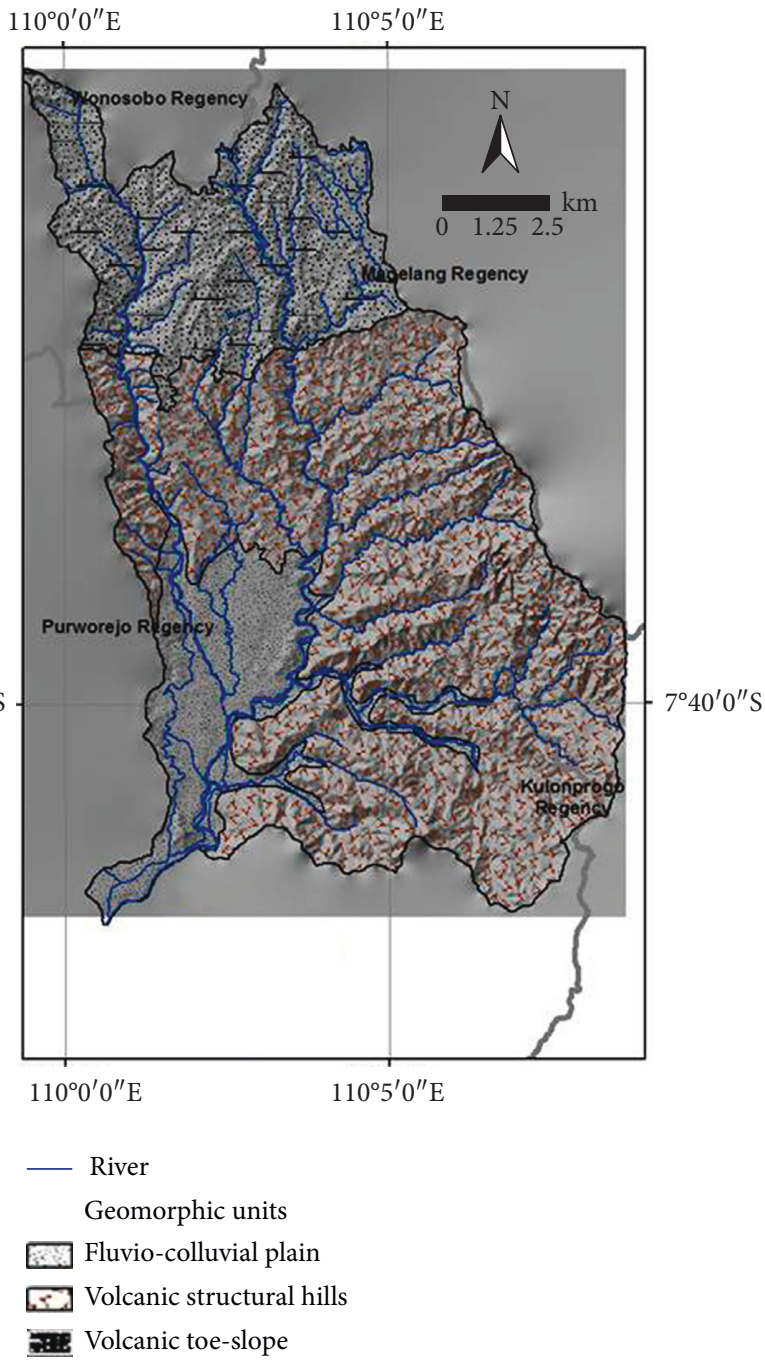

(c)

Figure 1

prone area with high density of agriculture livelihood. The study area is located in the southern part of Java. It is dominated by rough relief, and $65 \%$ of the area is covered by hilly areas (Figure 1), and hence, the area is highly prone to geomorphic processes. The area is a transitional landscape zone of Sumbing Quaternary Volcanic Systems and Menoreh Tertiary Volcanic-Structural Systems. Consequently, it has a unique geological relationship with soils, and most of it is underlain by weathered volcanic materials and covered by volcanic ash deposit or landslide deposit. In some areas, the geological relationship with soils is also induced by hydrothermal alteration that resulted in heavily altered volcanic materials. Variation of lithologies in different processes influences the characteristics of soils, which are crucial for landslides.

Generally, a short-term perspective of the impact of landslide had considered landslides as disasters. The processes and mechanism of landslides derived from hydrologic, geomorphologic, pedologic, and geotechnic perspectives are largely investigated. However, a comprehensive and a long-term ecological perspective of landslides have received less attention. The effects of landslides on physicochemical characteristics of soils and on local livelihood have not been well understood. This knowledge gap is better approached using the analysis of ecological perspective of landslides that could accommodate socioecologic aspects in the landslide prone area. It is important because local people are greatly dependent on land for crop production and for their sustainable livelihood. Thus, the study aimed at finding out the ecological roles of landslides in altering physicochemical characteristics of soils and their impact on local livelihood in the Middle Bogowonto Watershed.

\section{Materials and Methods}

2.1. Field Sampling. The soil sampling method used in the study was purposive sampling based on variation of uppermost soil materials in the study area such as volcanic ash deposit, weathered and altered andesitic breccias, weathered 
TABLe 1: Physicochemical properties of soils.

\begin{tabular}{|c|c|c|c|c|c|c|c|c|c|c|c|c|}
\hline \multirow{2}{*}{ Number } & \multirow{2}{*}{ Soil parent material } & \multirow{2}{*}{$\begin{array}{c}\text { Horizon } \\
\text { (depth in } \mathrm{cm} \text { ) }\end{array}$} & \multirow{2}{*}{ Texture } & \multicolumn{3}{|c|}{$\begin{array}{l}\text { Particle size } \\
\text { distribution }\end{array}$} & \multirow{2}{*}{$\begin{array}{c}\text { Base } \\
\text { saturation } \\
(\%)\end{array}$} & \multirow{2}{*}{$\begin{array}{c}\text { CEC } \\
(\mathrm{me} / 100 \mathrm{~g})\end{array}$} & \multicolumn{4}{|c|}{ Cation bases } \\
\hline & & & & $\begin{array}{c}\% \\
\text { clay }\end{array}$ & $\begin{array}{c}\% \\
\text { silt } \\
\end{array}$ & $\begin{array}{c}\% \\
\text { sand } \\
\end{array}$ & & & $\mathrm{Na}^{+}$ & $\begin{array}{l}\mathrm{K}^{+} \\
\text {(me }\end{array}$ & $\begin{array}{l}\mathrm{Ca}^{2+} \\
100 \mathrm{~g})\end{array}$ & $\mathrm{Mg}^{2+}$ \\
\hline \multirow{3}{*}{1} & \multirow{3}{*}{$\begin{array}{l}\text { Volcanic ash } \\
\text { materials }\end{array}$} & $\mathrm{A}(0-27)$ & Silt & 10.4 & 80.4 & 9.2 & 39.8 & 38.4 & 0.02 & 0.06 & 11.8 & 3.4 \\
\hline & & AC (27-68) & Silt & 5.8 & 81.6 & 12.7 & 37.1 & 23.6 & 0.02 & 0.05 & 5.1 & 3.6 \\
\hline & & $C(68-134+)$ & Silt loam & 8.2 & 67.1 & 24.7 & 50.0 & 20.7 & 0.02 & 0.05 & 6.1 & 4.2 \\
\hline \multirow{2}{*}{2} & \multirow{2}{*}{ Weathered marl } & A $(0-21)$ & Silty clay & 42.2 & 55.1 & 3.8 & 89.6 & 54.9 & 0.40 & 0.08 & 29.7 & 19.0 \\
\hline & & $C(21-96+)$ & Silty clay & 41.5 & 50.6 & 7.9 & * & 52.1 & 0.40 & 0.08 & 32.9 & 19.2 \\
\hline \multirow{2}{*}{3} & \multirow{2}{*}{ Weathered tuff } & A $(0-19)$ & Silt loam & 10.8 & 70.8 & 18.4 & $*$ & 64.1 & 0.17 & 0.50 & 49.7 & 24.3 \\
\hline & & C $(19-41+)$ & Silt loam & 8.6 & 76.9 & 14.5 & * & 47.9 & 0.19 & 0.50 & 50.9 & 26.7 \\
\hline \multirow{5}{*}{4} & \multirow{5}{*}{$\begin{array}{c}\text { Volcanic ash } \\
\text { materials- } \\
\text { weathered } \\
\text { andesitic breccias }\end{array}$} & $\mathrm{A}(0-28)$ & Silt & 20.7 & 70.1 & 9.2 & 41.7 & 30.2 & 0.02 & 0.06 & 7.6 & 4.9 \\
\hline & & Bw (28-49) & Clay & 41.8 & 37.6 & 20.7 & 47.2 & 25.6 & 0.03 & 0.06 & 7.8 & 4.2 \\
\hline & & C (49-92) & Silt loam & 13.6 & 61.3 & 25.1 & 53.2 & 23.1 & 0.03 & 0.07 & 8.3 & 3.9 \\
\hline & & $2 \mathrm{Bt}(92-160)$ & Clay & 46.6 & 32.6 & 20.8 & 71.7 & 29.2 & 0.21 & 0.65 & 14.3 & 5.8 \\
\hline & & $2 \mathrm{C}(160-188+)$ & Loam & 25.3 & 46.4 & 28.4 & 87.9 & 26.4 & 0.23 & 0.68 & 15.5 & 6.8 \\
\hline & Weathered & A $(0-30)$ & Silt loam & 18.2 & 70.6 & 11.2 & * & 18.3 & 0.18 & 0.51 & 12.1 & 6.2 \\
\hline 5 & $\begin{array}{l}\text { andesitic } \\
\text { breccias }\end{array}$ & C $(30-212+)$ & Silt loam & 11.3 & 73.2 & 15.4 & * & 27.9 & 0.20 & 0.58 & 16.2 & 7.4 \\
\hline & & $\mathrm{A}(0-31)$ & Silty clay & 48.6 & 36.5 & 14.9 & 41.2 & 7.0 & 0.03 & 0.06 & 2.2 & 0.6 \\
\hline & & $\mathrm{C}(31-74)$ & Silty clay loam & 29.3 & 50.2 & 20.5 & 34.3 & 6.9 & 0.03 & 0.04 & 2.1 & 0.2 \\
\hline & $\begin{array}{l}\text { Volcanic ash } \\
\text { materials-altered }\end{array}$ & 2B1 (74-97) & Clay & 79.4 & 16.7 & 3.9 & 40.6 & 7.3 & 0.02 & 0.05 & 2.3 & 0.6 \\
\hline 6 & & $2 \mathrm{~B} 2(97-170)$ & Clay & 81.5 & 16.3 & 2.2 & 39.4 & 7.8 & 0.03 & 0.05 & 2.3 & 0.7 \\
\hline & & 2BC (170-199) & Clay & 83.5 & 13.8 & 2.7 & 43.4 & 7.8 & 0.03 & 0.06 & 2.5 & 0.8 \\
\hline & & 2C (199-276+) & Clay & 80.5 & 15.7 & 3.8 & 43.0 & 8.1 & 0.03 & 0.06 & 2.6 & 0.8 \\
\hline & & A $(0-28)$ & Loam & 17.1 & 59.0 & 24.0 & 67.3 & 48.0 & 0.17 & 0.5 & 26.8 & 4.9 \\
\hline 7 & & Bw (28-47) & Silt loam & 17.5 & 63.2 & 19.2 & $*$ & 30.6 & 0.15 & 0.44 & 29.5 & 4.3 \\
\hline & & $\mathrm{C}(47-106+)$ & Loam & 16.9 & 61.1 & 22.0 & * & 33.3 & 0.18 & 0.53 & 30.1 & 3.8 \\
\hline & Weathered & A $(0-24)$ & Silt loam & 12.8 & 51.3 & 35.9 & 77.7 & 38.7 & 0.02 & 0.07 & 23.8 & 6.2 \\
\hline 8 & $\begin{array}{c}\text { andesitic } \\
\text { breccias }\end{array}$ & $\mathrm{C}(24-87+)$ & Sandy loam & 4.0 & 36.7 & 59.3 & 86.2 & 35.7 & 0.03 & 0.07 & 24.1 & 6.5 \\
\hline & & $A(0-22)$ & Sill tuant & 27.2 & 55.6 & 17.2 & 37.3 & 29.1 & 0.03 & 0.05 & 8.1 & 2.7 \\
\hline & & $\mathrm{Bw}(22-40)$ & Silty clay loam & 38.3 & 52.6 & 9.1 & 46.4 & 27.1 & 0.03 & 0.05 & 9.2 & 3.3 \\
\hline 9 & $n$ & C (40-87) & Silt loam & 23.4 & 54.2 & 22.4 & 60.0 & 23.8 & 0.02 & 0.06 & 10.8 & 3.4 \\
\hline & & 2C (87-149) & Silt loam & 18.8 & 50.3 & 30.9 & 67.1 & 19.8 & 0.03 & 0.07 & 8.8 & 4.4 \\
\hline & & 3C (149-191+) & Silt loam & 17.2 & 69.6 & 13.2 & 74.9 & 22.4 & 0.02 & 0.07 & 11.8 & 4.9 \\
\hline & & $\mathrm{A}(0-29)$ & Silt loam & 17.2 & 69.6 & 13.2 & 43.6 & 24.9 & 0.02 & 0.04 & 6.1 & 4.7 \\
\hline & & C (29-78) & Silt loam & 14.1 & 70.8 & 15.1 & 65.1 & 19.3 & 0.03 & 0.05 & 7.2 & 5.3 \\
\hline 10 & & $2 \mathrm{Bw}(78-96)$ & Silty clay loam & 30.8 & 54.6 & 14.6 & 32.6 & 29.3 & 0.02 & 0.05 & 5.8 & 3.7 \\
\hline & & $2 \mathrm{C}(96-168)$ & Silt loam & 19.8 & 50.3 & 29.9 & 46.9 & 26.8 & 0.02 & 0.07 & 8.2 & 4.3 \\
\hline & & $3 \mathrm{C}(168-220+)$ & Silt loam & 16.9 & 52.3 & 31.8 & 47.8 & 23.2 & 0.03 & 0.07 & 6.2 & 4.8 \\
\hline & & $\mathrm{A}(0-27)$ & Clay & 63.6 & 20.5 & 15.9 & 31.7 & 7.1 & 0.02 & 0.03 & 1.8 & 0.4 \\
\hline & & B1 (27-59) & Clay & 76.4 & 18.0 & 5.6 & 32.0 & 7.7 & 0.03 & 0.04 & 1.9 & 0.5 \\
\hline & Altered andesitic & B2 (59-90) & Clay & 87.3 & 11.6 & 1.1 & 33.2 & 8.3 & 0.02 & 0.04 & 2.1 & 0.6 \\
\hline 11 & & B3 (90-157) & Clay & 83.2 & 15.9 & 0.9 & 32.2 & 8.6 & 0.02 & 0.05 & 2.1 & 0.6 \\
\hline & & BC (157-216) & Clay & 62.4 & 31.2 & 6.4 & 36.7 & 8.4 & 0.03 & 0.06 & 2.4 & 0.6 \\
\hline & & $C(216-274+)$ & Clay & 63.0 & 23.5 & 13.5 & 35.5 & 8.7 & 0.03 & 0.06 & 2.4 & 0.6 \\
\hline 12 & Altered andesitic & $\mathrm{A}(0-26)$ & Clay & 66.6 & 27.0 & 6.4 & 67.6 & 38.7 & 0.03 & 0.08 & 21.8 & 4.3 \\
\hline 12 & & $C(26-91+)$ & Clay & 60.1 & 30.4 & 9.5 & 77.3 & 37.2 & 0.02 & 0.07 & 23.1 & 5.6 \\
\hline & Weathered & $\mathrm{A}(0-23)$ & Silt loam & 11.6 & 61.5 & 26.9 & 67.8 & 31.0 & 0.23 & 0.65 & 14.3 & 5.8 \\
\hline 13 & $\begin{array}{r}\text { andesitic } \\
\text { breccias }\end{array}$ & C (23-138+) & Silt loam & 10.9 & 55.0 & 34.0 & 90.3 & 25.8 & 0.24 & 0.68 & 15.5 & 6.8 \\
\hline & & $\mathrm{A}(0-28)$ & Clay & 66.2 & 25.0 & 8.8 & 67.9 & 50.1 & 0.21 & 0.61 & 24.4 & 8.8 \\
\hline 14 & Altered andesitic & AC (28-58) & Clay & 71.5 & 21.7 & 6.8 & * & 55.4 & 0.23 & 0.66 & 32.6 & 27.7 \\
\hline & & C (58-164) & Clay & 57.6 & 32.7 & 9.7 & $*$ & 56.4 & 0.23 & 0.68 & 35.1 & 28.4 \\
\hline & & $\mathrm{A}(0-27)$ & Clay & 77.5 & 18.5 & 4.1 & 44.9 & 28.8 & 0.03 & 0.08 & 8.3 & 4.5 \\
\hline 15 & Altered andesitic & Bt (27-69) & Clay & 85.7 & 12.1 & 2.2 & 67.3 & 19.4 & 0.03 & 0.08 & 6.8 & 6.1 \\
\hline & & $C(69-148+)$ & Clay & 58.2 & 34.5 & 7.3 & 64.7 & 24.6 & 0.03 & 0.08 & 9.3 & 6.4 \\
\hline
\end{tabular}


TABle 1: Continued.

\begin{tabular}{|c|c|c|c|c|c|c|c|c|c|c|c|c|}
\hline \multirow{2}{*}{ Number } & \multirow{2}{*}{ Soil parent material } & \multirow{2}{*}{$\begin{array}{c}\text { Horizon } \\
\text { (depth in } \mathrm{cm})\end{array}$} & \multirow{2}{*}{ Texture } & \multicolumn{3}{|c|}{$\begin{array}{l}\text { Particle size } \\
\text { distribution }\end{array}$} & \multirow{2}{*}{$\begin{array}{c}\text { Base } \\
\text { saturation } \\
(\%)\end{array}$} & \multirow{2}{*}{$\begin{array}{c}\text { CEC } \\
(\mathrm{me} / 100 \mathrm{~g})\end{array}$} & \multicolumn{4}{|c|}{ Cation bases } \\
\hline & & & & $\begin{array}{c}\% \\
\text { clay }\end{array}$ & $\begin{array}{c}\% \\
\text { silt } \\
\end{array}$ & $\begin{array}{c}\% \\
\text { sand } \\
\end{array}$ & & & $\mathrm{Na}^{+}$ & $\begin{array}{l}\mathrm{K}^{+} \\
(\mathrm{me}\end{array}$ & $\begin{array}{c}\mathrm{Ca}^{2+} \\
100 \mathrm{~g}) \\
\end{array}$ & $\mathrm{Mg}^{2+}$ \\
\hline \multirow{2}{*}{16} & \multirow{2}{*}{$\begin{array}{c}\text { Weathered } \\
\text { andesitic } \\
\text { breccias }\end{array}$} & A $(0-27)$ & Silt loam & 14.0 & 80.3 & 5.5 & 74.4 & 19.9 & 0.26 & 0.74 & 8.9 & 5.0 \\
\hline & & C (27-186) & Silt loam & 10.8 & 70.5 & 18.5 & 75.6 & 17.1 & 0.21 & 0.61 & 8.2 & 4.0 \\
\hline
\end{tabular}

${ }^{*}$ Not accessed.

marls, and weathered tuff. There were 16 soil profiles investigated here, which represented the variation of soil materials in the study area (Table 1). The profiles were described using the Guideline for Soil Description [15].

The ecological roles of landslide were examined through field empirical evidences in the form of observation of the landslide locations and direct measurement. The study was conducted with extensive field survey method in the key areas through census of the existing landslides. In the key areas, the study carried out field observations of the characteristics of the existing plant and crop and the water availability, while soil sampling was drawn for laboratory testing.

Stepwise interpretation was made from global to local scales using $1: 100,000-1: 25,000$ Indonesian topographic maps and remote sensing images of $30 \mathrm{~m}-<10 \mathrm{~m}$ spatial resolution. The data of the identified and measured parameters of the spatially correlated landslide occurrence were analyzed.

2.2. Sample Analyses. The 16 soil profiles were analyzed qualitatively and quantitatively. Qualitatively, soil profile development was directly described using in-field horizon differentiation. Meanwhile, quantitative soil profile development was analyzed in the laboratory. Some laboratory tests of soil physical properties were conducted, including texture, bulk density, permeability, structure, and index plasticity. The textures were measured in $\Phi<2 \mathrm{~mm}$ of airdried soil particles. The particle sizes criteria were based on the USDA classification system: sand $(\Phi 2 \mathrm{~mm}-0.05 \mathrm{~mm})$, silt $(\Phi 0.05 \mathrm{~mm}-0.002 \mathrm{~mm})$, and clay $(\Phi<0.002 \mathrm{~mm})$. The organic carbon $(\mathrm{C})$ was measured using the wet method by Walkley and Black [16]. The organic carbon (C) is multiplied with a conversion number (1.724) to obtain SOM content. The CEC analysis of $\mathrm{NH}_{4} \mathrm{OAc}$ was made at $\mathrm{pH} 7.0$ and followed by distillation of soil-filtered sample. The liquid resulting from the CEC extraction (aliquot) was used in the analysis of cation bases $\left(\mathrm{Na}^{+}, \mathrm{K}^{+}, \mathrm{Ca}^{2+}\right.$, and $\left.\mathrm{Mg}^{2+}\right)$. The analysis of mineralogical properties was made to detect the crystalline and noncrystalline minerals. The analysis also aimed at determining the clay type. XRPD (X-ray powder diffraction) was carried out in this analysis using the Bruker D8 Advance scanner tool. XRF was also conducted to measure total elements quantitatively.

\section{Results}

The results showed that the dominant texture in the profiles were clay and silt loam (Table 1). The texture controlled the characteristics of soils in the study area. Most of the soil profiles showed that the texture of surface horizon was finer than that of $\mathrm{C}$ horizon. However, soils that developed from altered volcanic materials had dominant fine textures in all horizons.

Most of the soils in the study area were indicative of high clay content $(>60 \%)$. It was considered as extreme clay content because the percentage of clay in usual soils that developed from weathered materials was $\leq 30 \%$ (Table 1 ). Such extreme clay content was only possible because of the heat-relating alteration process that induced intensive transformation of primary minerals into secondary minerals [17]. It showed that the alteration process of volcanic rock became the main determinant factor of the high clay content of certain soil profiles in the study area as shown in profiles 6 , 11, 12, 14, and 15 (Table 1).

The domination of volcanic ash deposits and altered volcanic materials as surface materials was the causal factor of the soils with the extreme clay content in the study area. This extreme clay content (Table 1) was possibly formed by feldspar kaolinization [18] as the alteration process changed the feldspar mineral in volcanic rocks into kaolinite minerals [17]. It was corroborated by the study of Zhang et al. [19] and stated that intensive magmatic activities produced clayaltered materials due to mineralization of metallic sulfide deposits that related to volcanic materials. Therefore, the mineral compositions of the parent rock in the study area became the main determinant factor of the extreme clay content in the altered volcanic materials [20]. Additionally, the other author confirmed that the major cation bases $\mathrm{Ca}^{2+}$, $\mathrm{Mg}^{2+}$, and $\mathrm{Na}^{+}$generally decreased with the increase in alteration intensity [17]. It meant that the amount of the major cation bases was lower in the soils that developed from altered volcanic materials than those in the soils that developed from weathering materials, as shown in Table 1.

The high clay content of the soils might cause solid soil in the profiles. Furthermore, it was found that the clay layers in the hilly region of the study area were very thick. The field measurement on the particular outcrops showed that the depth of the clay layers in a profile was more than $10 \mathrm{~m}$ (Table 2). Moreover, the previous study in the study area showed that a prediction based on geoelectric measurement showed the depth of the clay layers was more than $150 \mathrm{~m}$. Each of the clay layers had its own genetic formation and hence resulted in different clay sensitivity (Table 3 ). The lower clay layer performed ancient hydrothermal action. The middle clay layer developed from old-volcanic ash. The upper clay layer was the result of typical soil development where the clay layer was indicative of B-horizon performance. The uppermost $2 \mathrm{~m}$ of the 
TABLe 2: Selective samples of clay layer depth.

\begin{tabular}{lccc}
\hline $\begin{array}{l}\text { Sample } \\
\text { code }\end{array}$ & $\begin{array}{c}\text { Layer } \\
\text { position } \\
(\mathrm{m})\end{array}$ & $\begin{array}{c}\text { Layer } \\
\text { depth } \\
(\mathrm{m})\end{array}$ & $\begin{array}{c}\text { Elevation } \\
\text { (mdpal) }\end{array}$ \\
\hline L2L1 & 0 & 14.62 & 437.50 \\
L2L2 & 14.62 & 3.11 & 422.88 \\
L2L3 & 17.73 & 0.93 & 419.77 \\
L2L4 & 18.66 & 0.60 & 418.84 \\
L2L5a & 19.26 & 0.41 & 418.24 \\
L2L5b & 19.67 & 0.53 & 417.83 \\
\hline L3L1 & 0 & 3.32 & 432 \\
L3L2 & 3.32 & 3.55 & 428.68 \\
L3L3 & 6.87 & 2.45 & 425.13 \\
L3L4 & 9.32 & 2.63 & 422.68 \\
\hline S & & &
\end{tabular}

Source: Budianto [23].

soil layer developed from young volcanic ash. The condition became the major barrier for the cultivation in agricultural land.

Kaolinite was the dominant clay type in the study area [20]. Therefore, the soil order in the study area was in general Inceptisols. Kaolinite was a 1:1 clay layer, and dehydrates more than halloysite [21]. The domination of kaolinite in soils that developed from weathered volcanic materials made sense because the halloysite might undergo transition into kaolinite in humid-tropical climate as a result of advanced stage of weathering of volcanic materials [22].

The kaolinite clay type was strongly indicative of the formation of clay slip. The clay slip became a determinant factor in triggering landslides since it related to shear strength of soils. It triggered the landslides and might result in an interlayer between the unconsolidated upper layer (soil) and the consolidated underlying layer (weathered parent rocks). In contrast to the smectite clay type that controlled the landslide because of its swelling properties, the kaolinite clay type might control the landslide because of its slip characteristic. The study by Budianto [23] showed that the study area had soft clay type considering the cohesion value and the free shear strength of soils. Consequently, stresses in the soft clay layer could in the situation which easily changes the structure of the clay that triggered the landslides.

These very thick clay layers were mostly found in the profiles induced by hydrothermal alteration. Based on field observation, these thick layers were caused by several B-horizons as indicated by layering of argillic horizons under different intensities. Pratiwi [24] showed that the prediction based on geoelectric measurement results in clay layers which more than $150 \mathrm{~m}$ thick. It was corroborated by the study of Pirajno [25] who found that the hydrothermal alteration might generate argillic and result in the formation of clay minerals because of the increase in $\mathrm{H}^{+}$activities during the alteration sequence of the metasomatism process in which the mineral exchange occurred between the altered rocks and the ions carried by water [26].

The clay sensitivity level decreased with the increase in soil water content. It was clearly observed in Table 3 that most of the soil layers had high clay sensitivity. Consequently, it became the primary proof of the formation of the clay slip in the study area. This high clay sensitivity was established when the liquid limit was lower than the soil water content.

The domination of the kaolinite type in the study area resulted in significant relation to saturated CEC, cation bases, and base in the profiles. The kaolinite had difficulties in absorbing cations [27]. Therefore, the clay type caused very low CEC values $(<10 \mathrm{me} / 100 \mathrm{~g})$. The very low exchanging capacity of cations caused very low rate of base cations $\left(\mathrm{Na}^{+}, \mathrm{K}^{+}, \mathrm{Ca}^{2+}\right.$, and $\left.\mathrm{Mg}^{2+}\right)$ and hence resulted in very low saturated base.

The quantitative mineralogical analysis of soil parent materials was made in the study using X-ray Fluorescence (XRF) to complete the qualitative mineralogical analysis. The results of the XRF showed that $\mathrm{SiO}_{2}$ was the dominant mineral (Table 4). The presence of the $\mathrm{SiO}_{2}$ indicated that the parent rock has been weathered and altered intensively so that those processes leached the major and minor minerals and alkali elements of the parent rock [28]. The results of the analysis showed that the major minerals contained in all soil parent materials were $\mathrm{SiO}_{2}, \mathrm{Al}_{2} \mathrm{O}_{3}$, and $\mathrm{Fe} 2 \mathrm{O} 3$, while the major alkali elements were $\mathrm{O}, \mathrm{Fe}, \mathrm{Si}$, and $\mathrm{Al}$ (Table 4).

\section{Discussion}

The presence of very thick clay layers caused several difficulties in land management because the thick clay layer had massive, hard, and consistent soil structure. It caused particularly high incidence of landslides. Additionally, the crops cultivated in the land with the very thick clay layers did not grow well. The landslides were considered as a significant factor in the redistribution of the soils in the study area. During the redistribution of the soils, they not only removed the surface soil layer but also certain amount of slope materials as a hillslope deposit [29-31]. They could redistribute soils abruptly and faster because they could redistribute soils from upper to lower slopes in a large block of soils.

The impact of the landslides in the study area on the redistribution of soils was observed in the formation of the three zones of landform, that is residual, erosional, and depositional zones (Figure 2). The residual zone was located in the peak areas of interfluves hills. The soils in the residual zone had massive soil structure and very hard consistency due to the occurrence of high content of clay (Table 1). The residual zone, as the area that has not slid yet, was limited in land resources, and it was difficult to apply a good soil management practice in it.

The occurrence of the erosional zone as upper slope and the depositional zone as lower slope showed the presence of landslides. The erosional zone might act as water recharge areas for the depositional zone at the lower slopes. In the areas of active landslide, the environmental conditions seemed to be more favorable for the survival of living creatures. The soils in the erosional zone consisted of secondary pores in the forms of cracks due to limited soil movement. The presence of the soil cracks ensured air and water movement in the soils that enabled vegetation to grow better. It was clearly observed in Table 5 that the soils in the 
TABLE 3: Selective samples of sensitivity level of clay.

\begin{tabular}{|c|c|c|c|c|c|}
\hline Sample code & Liquid limit (BC) & Liquidity index (LI) & Soil water content (KA) & $\begin{array}{c}\text { Sensitivity level } \\
\mathrm{BC}<\mathrm{KA}\end{array}$ & $\begin{array}{l}\text { Sensitivity } \\
\text { LI }>0.5-4\end{array}$ \\
\hline L2L1 & 67.57 & 1.09 & 68.86 & High & Sensitive clay \\
\hline L2L2 & 98.07 & 0.99 & 97.58 & Medium & Sensitive clay \\
\hline L2L3 & 67.70 & 1.14 & 69.61 & High & Sensitive clay \\
\hline L2L4 & 74,52 & 0.91 & 73.08 & Medium & Sensitive clay \\
\hline L2L5a & 75.47 & 0.95 & 74.29 & Medium & Sensitive clay \\
\hline L2L5b & 83.81 & 1.03 & 84.62 & High & Sensitive clay \\
\hline L3L1 & 64.21 & 1.07 & 65.19 & High & Sensitive clay \\
\hline $\mathrm{L} 3 \mathrm{~L} 2$ & 89.29 & 0.97 & 88.45 & Medium & Sensitive clay \\
\hline L3L3 & 78.63 & 1.49 & 81.24 & High & Sensitive clay \\
\hline $\mathrm{L} 3 \mathrm{~L} 4$ & 94.23 & 1.15 & 95.48 & High & Sensitive clay \\
\hline
\end{tabular}

Source: Budianto [23].

TABLE 4: Selective sample of XRF analysis in weathered materials.

\begin{tabular}{|c|c|c|c|c|c|c|}
\hline & \multicolumn{3}{|c|}{ Weathered material 1} & \multicolumn{3}{|c|}{ Weathered material 2} \\
\hline & Formula & $Z$ & Concentration & Formula & $Z$ & Concentration \\
\hline \multirow{20}{*}{ Minerals } & $\mathrm{SiO}_{2}$ & 14 & $37.89 \%$ & $\mathrm{SiO}_{2}$ & 14 & $29.53 \%$ \\
\hline & $\mathrm{Fe}_{2} \mathrm{O}_{3}$ & 26 & $27.87 \%$ & $\mathrm{Fe}_{2} \mathrm{O}_{3}$ & 26 & $28.02 \%$ \\
\hline & $\mathrm{Al}_{2} \mathrm{O}_{3}$ & 13 & $27.69 \%$ & $\mathrm{Al}_{2} \mathrm{O}_{3}$ & 13 & $22.81 \%$ \\
\hline & $\mathrm{TiO}_{2}$ & 22 & $2.49 \%$ & $\mathrm{Na}_{2} \mathrm{O}$ & 11 & $9.98 \%$ \\
\hline & $\mathrm{P}_{2} \mathrm{O}_{5}$ & 15 & $0.78 \%$ & $\mathrm{MgO}$ & 12 & $2.54 \%$ \\
\hline & $\mathrm{CaO}$ & 20 & $0.68 \%$ & $\mathrm{TiO}_{2}$ & 22 & $1.91 \%$ \\
\hline & $\mathrm{MnO}$ & 25 & $0.62 \%$ & $\mathrm{CaO}$ & 20 & $1.11 \%$ \\
\hline & $\mathrm{SO}_{3}$ & 16 & $0.52 \%$ & $\mathrm{P}_{2} \mathrm{O}_{5}$ & 15 & $0.82 \%$ \\
\hline & $\mathrm{Cl}$ & 17 & $0.43 \%$ & $\mathrm{~K}_{2} \mathrm{O}$ & 19 & $0.75 \%$ \\
\hline & $\mathrm{K}_{2} \mathrm{O}$ & 19 & $0.35 \%$ & $\mathrm{SO}_{3}$ & 16 & $0.70 \%$ \\
\hline & $\mathrm{Nd}_{2} \mathrm{O}_{3}$ & 60 & $0.17 \%$ & $\mathrm{Cl}$ & 17 & $0.52 \%$ \\
\hline & $\mathrm{SrO}$ & 38 & $0.12 \%$ & $\mathrm{MnO}$ & 25 & $0.25 \%$ \\
\hline & $\mathrm{Pr}_{6} \mathrm{O}_{11}$ & 59 & $0.10 \%$ & $\mathrm{La}_{2} \mathrm{O}_{3}$ & 57 & $0.17 \%$ \\
\hline & $\mathrm{ZrO}_{2}$ & 40 & $0.06 \%$ & $\mathrm{CeO}_{2}$ & 58 & $0.15 \%$ \\
\hline & $\mathrm{ZnO}$ & 30 & $0.04 \%$ & $\mathrm{Nd}_{2} \mathrm{O}_{3}$ & 60 & $0.13 \%$ \\
\hline & $\mathrm{CuO}$ & 29 & $0.04 \%$ & $\mathrm{ZrO}_{2}$ & 40 & $0.12 \%$ \\
\hline & $\mathrm{Cr}_{2} \mathrm{O}_{3}$ & 24 & $0.03 \%$ & $\mathrm{Pr}_{6} \mathrm{O}_{11}$ & 59 & $0.07 \%$ \\
\hline & $\mathrm{CeO}_{2}$ & 58 & $0.03 \%$ & $\mathrm{~V}_{2} \mathrm{O}_{5}$ & 23 & $0.07 \%$ \\
\hline & $\mathrm{Ga}_{2} \mathrm{O}_{3}$ & 31 & $0.02 \%$ & $\mathrm{CuO}$ & 29 & $0.05 \%$ \\
\hline & $\mathrm{SnO}_{2}$ & 50 & $0.02 \%$ & & & \\
\hline \multirow{19}{*}{ Alkali elements } & $\mathrm{O}$ & 8 & 46.13 & $\mathrm{O}$ & 8 & 40.83 \\
\hline & $\mathrm{Fe}$ & 26 & 21.08 & $\mathrm{Fe}$ & 26 & 19.60 \\
\hline & $\mathrm{Si}$ & 14 & 16.73 & $\mathrm{Si}$ & 14 & 13.81 \\
\hline & $\mathrm{Al}$ & 13 & 13.35 & $\mathrm{Al}$ & 13 & 12.07 \\
\hline & $\mathrm{Ti}$ & 22 & 0.75 & $\mathrm{Na}$ & 11 & 7.41 \\
\hline & $\mathrm{Ca}$ & 20 & 0.41 & $\mathrm{Mg}$ & 12 & 1.53 \\
\hline & $\mathrm{Mn}$ & 25 & 0.33 & $\mathrm{Ti}^{\circ}$ & 22 & 1.14 \\
\hline & $\mathrm{Cl}$ & 17 & 0.27 & $\mathrm{Ca}$ & 20 & 0.79 \\
\hline & $\mathrm{P}$ & 15 & 0.26 & $\mathrm{~K}$ & 19 & 0.62 \\
\hline & $\mathrm{K}$ & 19 & 0.19 & $\mathrm{Cl}$ & 17 & 0.52 \\
\hline & S & 16 & 0.15 & $\mathrm{P}$ & 15 & 0.36 \\
\hline & $\mathrm{Nd}$ & 60 & 0.14 & S & 16 & 0.28 \\
\hline & $\mathrm{Sr}$ & 38 & 0.05 & $\mathrm{Mn}$ & 25 & 0.19 \\
\hline & Pr & 59 & 0.04 & $\mathrm{La}$ & 57 & 0.15 \\
\hline & $\mathrm{Zr}$ & 40 & 0.02 & $\mathrm{Ce}$ & 58 & 0.12 \\
\hline & $\mathrm{Zn}$ & 30 & 0.02 & $\mathrm{Nd}$ & 60 & 0.11 \\
\hline & $\mathrm{Cu}$ & 29 & 0.02 & $\mathrm{Zr}$ & 40 & 0.09 \\
\hline & $\mathrm{Ce}$ & 58 & 0.01 & $\mathrm{Pr}$ & 59 & 0.06 \\
\hline & $\mathrm{Cr}$ & 24 & 0.01 & $\mathrm{Cu}$ & 29 & 0.04 \\
\hline
\end{tabular}




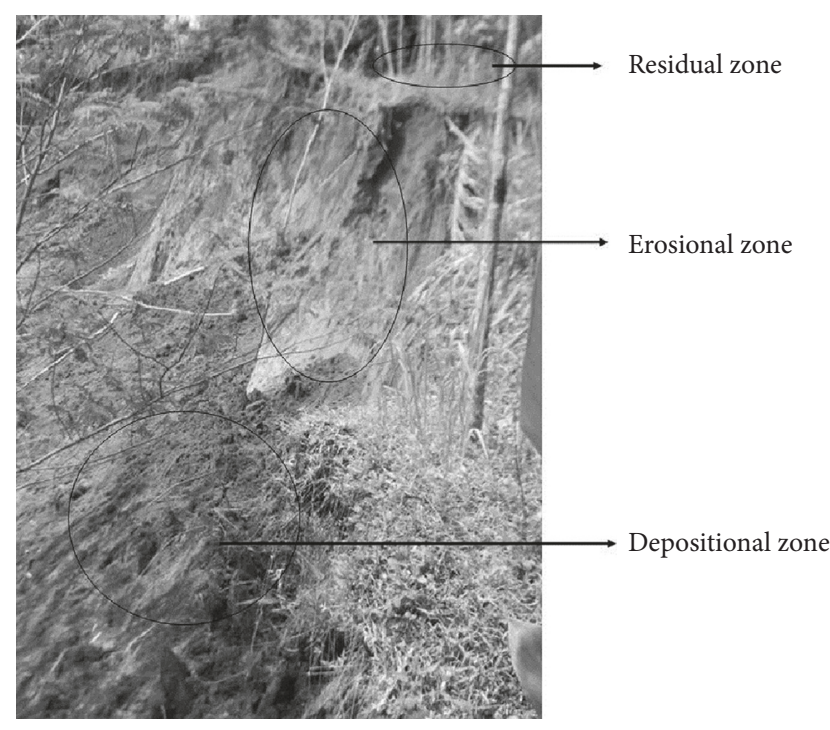

FIgURe 2: Zones in landslide prone area.

TABLE 5: Selective samples of soil properties at erosional and depositional zones.

\begin{tabular}{lccccc}
\hline Sample code & Texture & Cole index & \multicolumn{2}{c}{$\begin{array}{c}\text { Permeability } \\
(\mathrm{cm} / \text { jam })\end{array}$} \\
\hline S8-17 & Silt loam & 0.151 & High & 13.737 & Fast \\
S9-17 & Silt loam & 0.128 & Medium & 14.338 & Fast \\
S3-24 & Loam & 0.130 & Medium & 35.746 & Very fast \\
S4-24 & Silt loam & 0.109 & Medium & 10.750 & Slightly fast \\
S11-24 & Loam & 0.037 & Low & 28.062 & Very fast \\
S10-24 & Loam & 0.037 & Low & 30.263 & Very fast \\
S11-17 & Loam & 0.049 & Low & 8.093 & Slightly fast \\
S5-06 & Sandy loam & 0.076 & Medium & 6.335 & Slightly fast \\
S3-06 & Loam & 0.073 & Medium & 49.132 & Very fast \\
\hline
\end{tabular}

Source: Candraningrum [32].

erosional and depositional zones of the landslide body were indicative of slightly fast to very fast permeability. Also, the data showed that the Cole index in the samples was in the range of low to medium. The Cole index and the permeability were the properties that closely related to the clay content of the soils. Low clay content of the soils would result in low Cole index and was followed by the high rate of permeability. Consequently, the data of the properties resulting from the erosional and depositional zones (Table 5) showed that the clay content in the zones was not as effective as that in the residual zone. There has been a decrease in the clay content in the erosional and depositional zones as compared to that in the residual zone because of the presence of landslide activities. As a proof, it can be shown by the productivity of palm sugar from coconut trees and other agricultural products in the depositional zones which was higher than that in the residual zones.

Therefore, in the ecological perspective, the landslides might provide people with benefits in the land management of high clay areas. On the one hand, the erosional zone in the landslide body might act as the water recharge area for the depositional zone at lower slope. On the other hand, the landslides have resulted in depositional zones with relatively gentle slopes, which usually ranged from $4^{\circ}$ to $15^{\circ}$ and higher water availability. Therefore, local people could use the depositional zone in the landslide body as agricultural land. It was because the soils were of friable structure and had high content of soil organic matters that ensured its high capacity to support the growth of crops indicated by stand height, stem diameter, enough leaves, and good roots.

In this case, the landslides had good impact rather than bad impact on land. They played a significant role in redistributing soils from upper slope to lower slope. Consequently, landslide-redistributed soil materials were the results of the removal of the cover materials from the upper/middle slopes downward to the lower slopes in large quantities $[29,33]$. The landslide-redistributed soil materials were potential for immediate cultivation (Figure 3). It was because of the landslideredistributed soil materials that the soil aggregate stability usually decreased and soil moisture changed [34, 35]. Furthermore, the landslide-redistributed soil materials were contained by mixed soil materials that usually produced weak soil aggregates, and hence, it was easier for plants to grow on the soil materials as growing medium.

Different types of landslide-redistributed soil materials gave different cultivation possibilities. Unconsolidated landslide-redistributed soil materials, as entirely consisted of soils, were proper mainly for the cultivation of the crops such as cassava, long bean, curcuma, ginger, and sweet potato (Figure 3(a)). On one hand, the domination of soils in the landslide-redistributed soil materials was the causal factor of the inability of the soil to adequately hold wood plants. On the other hand, mixed landslide-redistributed soil materials might involve soils and saprolith. The mixed landslideredistributed soil materials were proper for the cultivation of wood plants such as teak wood (Tectona grandis) and sengon (Albasia marina) (Figure 3(b)). Actually, the mixed soil materials made the soil more stable, and hence, they were proper for the cultivation of wood plants.

The landslide-redistributed soil materials in some areas were also potential as the natural water storage [20]. The soils dominated by clayey materials were highly capable of storing infiltration water because of finer soil aggregates. Different permeability of landslide-redistributed soil materials and the underlying materials might initiate the occurrence of seepage. Consequently, most seepage was found around the toe landslide deposits. The higher capability of water storage in landslide-redistributed soil materials would enable the soils to better support plant growth than the residual soils.

In landslide prone areas like the study area, the landslideredistributed soil materials became predominant cover materials and hence acted as new soil parent materials. For a long time, they have been commonly recognized as soil parent materials [27] because they contributed to the creation of new pedogenesis [31]. These soil materials also caused lateral variation of the uppermost soil parent materials in the study area. Consequently, their presence on slope surface interrupted the influence of underlying soil development $[31,36]$ and hence brought about new soil formation. 


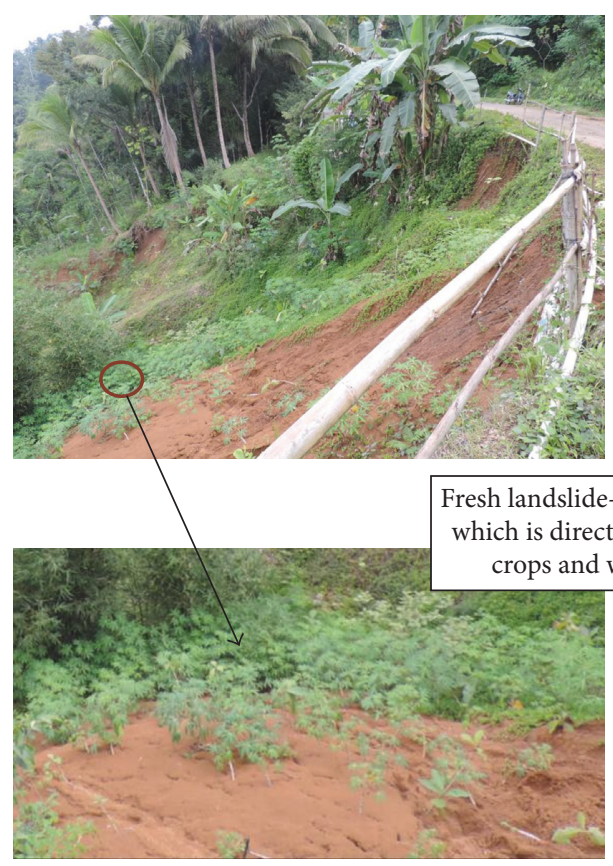

(a)

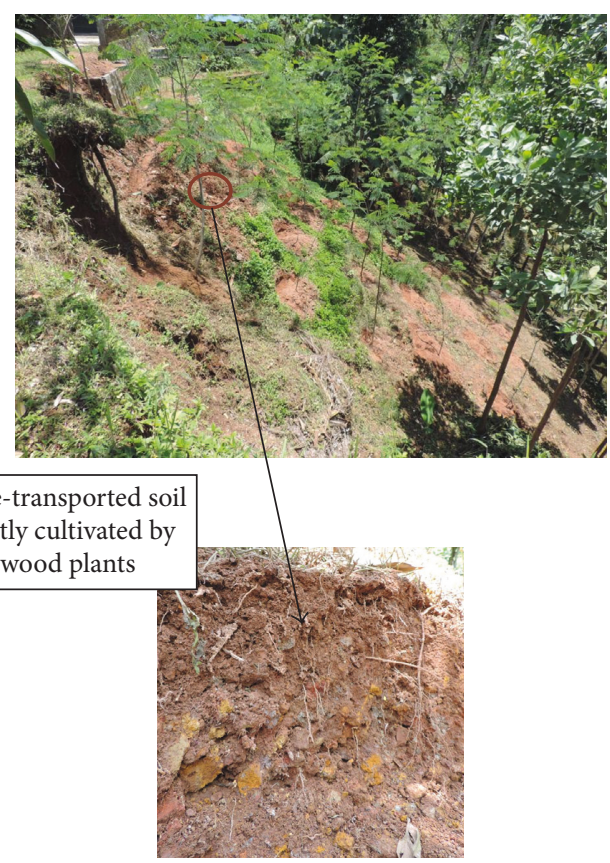

(b)

FIGURE 3: Cultivated landslide-redistributed soil materials: (a) unconsolidated landslide-redistributed soil materials; (b) mixed landslideredistributed soil materials.

\section{Conclusions}

The ecological roles of landslides are described through field empirical evidences in landslide locations that are cultivated by local people as agricultural land. This study concludes that the active landslide areas are having better vegetation cover. The surface material movement due to landslides has removed the residual zone in which the structure of the soils is massive and the consistency is very hard because of high clay content. Additionally, the landslides have created depositional zone with relatively gentle slopes, higher water availability, easier soil management, and better soil characteristics for cultivation. Crops grow well in this zone. Thus, the landslides might act as the rearrangement process of landforms for better living environment, especially in areas with high clay content. The use of land resources should follow the natural arrangement of landform to achieve land sustainability and to avoid unexpected landslide event in the future.

\section{Data Availability}

The data used to support the findings of this study are available from the corresponding author upon request.

\section{Disclosure}

The earlier version of this work was presented at 13th International Conference of the East and Southeast Asia Federation of Soil Science Societies, 2017.

\section{Conflicts of Interest}

The authors declare that there are no conflicts of interest.

\section{Acknowledgments}

The authors are very grateful to OeAD-Austria and DIKTIPPS (Contract no. 1790/UN1/DITLIT/DIT-LIT/LT/2018) for research grants. The authors would like to thank Professor Johann Stoetter and Professor Clemens Geitner from University of Innsbruck, Austria, for their valuable discussion during the research. The authors also thank Elok Surya Pratiwi, Yoesep Budianto, and Zuhara Candraningrum from Department of Environmental Geography, Universitas Gadjah Mada, for their supporting data to this paper.

\section{References}

[1] P. Salvati, C. Bianchi, M. Rossi, and F. Guzzetti, "Societal landslide and flood risk in Italy," Natural Hazards and Earth System Science, vol. 10, no. 3, pp. 465-483, 2010.

[2] T. Davies, S. Beaven, D. Conradson et al., "Towards disaster resilience: a scenario-based approach to co-producing and integrating hazard and risk knowledge," International Journal of Disaster Risk Reduction, vol. 13, pp. 242-247, 2015.

[3] M. G. Winter, S. Barbara, P. Derek, P. David, H. Clare, and S. Jonathan, "The economic impact of landslides and floods on the road network," Procedia Engineering, vol. 143, pp. 14251434, 2016.

[4] M. I. Kim, B. G. Chae, and G. C. Jeong, "Correlation of unsaturated soil and dielectric property for monitoring of subsurface characteristics: development of unsaturated dielectric mixing models and its application," Environmental Geology, vol. 57, no. 1, pp. 49-58, 2009.

[5] R. L. Ray and J. M. Jacobs, "Relationships among remotely sensed soil moisture, precipitation and landslide events," Natural Hazards, vol. 43, no. 2, pp. 211-222, 2007. 
[6] K. Cui and Z. C. Ling, "A mechanical investigation on altered rocks in tunnel construction," Advanced Materials Research, vol. 366, pp. 498-501, 2012.

[7] G. C. Jeong, K. S. Kim, C. O. Choo, J. T. Kim, and M. I. Kim, "Characteristics of landslides induced by a debris flow at different geology with emphasis on clay mineralogy in South Korea," Journal of Natural Hazards, vol. 59, no. 1, pp. 347365, 2011.

[8] K. Rankka, Y. Andersson-Sköld, C. Hultén, R. Larsson, V. Leroux, and T. Dahlin, "Quickclay in Sweden,"Technical report number 65, p. 137, Swedish Geotechnical Institute, Linköping, Sweden, 2004.

[9] A. E. Erginal, B. Özturk, Y. L. Ekinci, and A. Demirci, "Investigation of the nature of slip surface using geochemical analyses and 2-D electrical resistivity tomography: a case study from Lapseki area, NW Turkey," Environmental Geology, vol. 58, no. 6, 2009.

[10] G. F. Moore, A. Taira, A. Klaus et al., "New insights into deformation and fluid flow processes in the Nankai Trough accretionary prism: results of Ocean Drilling Program Leg 190," Geochemistry, Geophysics, Geosystems, vol. 2, no. 10, p. 1058, 2001.

[11] D. M. Saffer, C. Marone, K. M. Frye, and K. Mair, "Laboratory results indicating complex and potentially unstable frictional behavior of smectite clay," Geophysical Research Letters, vol. 28, no. 12, pp. 2297-2300, 2001.

[12] B. P. Wen and A. Aydin, "Deformation history of a landslide slip zone in light of soil microstructure," Environmental and Engineering Geoscience, vol. 2, pp. 123-149, 2004.

[13] M. Schäbitz, C. Janssen, H. R. Wenk et al., "Microstructures in landslides in northwest China-Implications for creeping displacements?," Journal of Structural Geology, vol. 106, pp. 70-85, 2018.

[14] S. Wang, A. Malehmir, and M. Bastani, "Geophysical characterization of areas prone to quick-clay landslides using radio-magnetotelluric and seismic methods," Techtonophysics, vol. 677-678, pp. 248-260, 2016.

[15] FAO, Guidelines for Soil Description, FAO, Rome, Italy, 4th edition, 2006.

[16] A. Walkley and I. A. Black, "An examination of Degtjareff method for determining soil organic matter and a proposed modification of the chromic acid titration method," Soil Science, vol. 37, no. 1, pp. 29-38, 1934.

[17] D. J. Bove, M. A. Mast, J. B. Dalton, W. G. Wright, and D. B. Yager, "Major styles of mineralization and hydrothermal alteration and related solid- and aqueous-phase geochemical signatures," in Integrated Investigations of Environmental Effects of Historical Mining in the Animas River Watershed, San Juan County, Colorado, S. E. Church, P. von Guerard, and S. E. Finger, Eds., Professional Paper, USGS, Reston, VA, USA, 2007.

[18] Q. Sun, "Rock alteration in a hydraulic engineering project in Southwest China," Arabian Journal of Geosciences, vol. 8, no. 1, pp. 23-27, 2015.

[19] Y. S. Zhang, Y. X. Qu, and J. R. Liu, "Engineering geological research on altered rocks in the area of NW Yunnan along Yunnan-Tibet Railway line," Chinese Journal of Geotechnical Engineering, vol. 29, no. 4, pp. 531-536, 2007, in Chinese.

[20] N. A. Pulungan, "Spatial patterns of soil characteristics and soil formation in the transitional landscape zone, central part of bogowonto catchment, Java, Indonesia," Ph.D. thesis, Innsbruck University, Innsbruck, Austria, 2016.

[21] A. Meuniers, Clays, Springer, Berlin, Germany, 2005.
[22] K. Wada, Y. Kakuto, and F. N. Muchena, "Clay minerals and humus complexes in five Kenyan soils derived from volcanic ash," Geoderma, vol. 39, no. 4, pp. 307-321, 1987.

[23] Y. Budianto, Keterdapatan Sensitive Clay Pada Lokasi Longsor Lahan di DAS Bompon, Kabupaten Magelang, Skripsi, Universitas Gadjah Mada, Yogyakarta, Indonesia, 2016.

[24] E. S. Pratiwi, "Integrasi metode geofifika dan geokimia untuk investigasi material dan mekanisme longsor tipe rotational slide di DAS Bompon, kabupaten magelang," Thesis, Universitas Gadjah Mada, Yogyakarta, Indonesia, 2017.

[25] F. Pirajno, Hydrothermal Processes and Mineral Systems, Springer, Sydney, NSW, Australia, 2009.

[26] D. H. Carlson, C. C. Plummer, and L. Hammersley, Physical Geology: Earth Revealed, McGraw Hill, New York, NY, USA, 9th edition, 2009.

[27] P. W. Birkeland and R. M. Burke, "Soil catena chronosequences on eastern Sierra Nevada moraines, California, U.S.A," Arctic and Alpine Research, vol. 20, no. 4, pp. 473-484, 1988.

[28] Z. Klika, Z. Weiss, and M. Mellini, "Water leaching of alkaline metals, $\mathrm{Al}$, and Si from selected aluminosilicates," Acta Geodynamica et Geomaterialia, vol. 2, no. 4, pp. 81-90, 2005.

[29] R. B. Daniels and R. D. Hammer, Soil Geomorphology, John Wiley and Sons, New York, NY, USA, 1992.

[30] S. H. Jien, T. H. Chen, C. Y. Chiu, and S. Nagatsuka, "Relationships between soil mass movement and relief in humid subtropical low-elevation mountains," Soil Science, vol. 174, no. 10, pp. 563-573, 2009.

[31] A. Kleber, "Cover-beds as soil parent materials in midlatitude regions," Catena, vol. 30, no. 2-3, pp. 197-213, 1997.

[32] Z. R. Candraningrum, "Hubungan mikrorelief dengan karakteristik material tanah permukaan di wilayah longsor aktif," M.Sc. thesis, Universitas Gadjah Mada, Yogyakarta, Indonesia, 2014.

[33] R. G. Hilton, A. Galy, A. J. West, N. Hovius, and G. G. Roberts, "Geomorphic control on the $15 \mathrm{~N}$ of mountain forests," Biogeosciences, vol. 10, no. 3, pp. 1693-1705, 2013.

[34] D. Alexander, "On the causes of landslides: human activities, perception, and natural processes," Environmental Geology and Water Sciences, vol. 20, no. 3, pp. 165-179, 1992.

[35] J. Malgot and F. Baliak, "The influence of human activity on the development of landslides in Slovakia," Geograficky Casopis, vol. 54, no. 1, pp. 21-38, 2002.

[36] J. D. Phillips, "Geogenesis, pedogenesis, and multiple causality in the formation of texture-contrast soils," Catena, vol. 58, no. 3, pp. 275-295, 2004. 

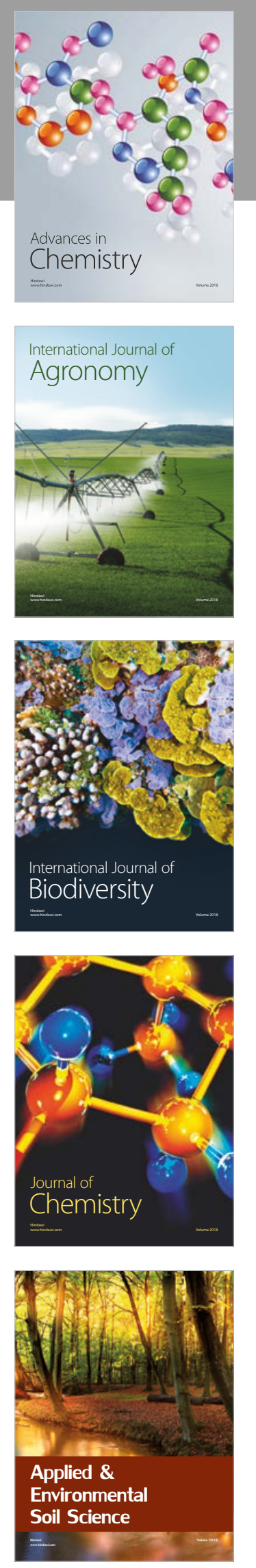

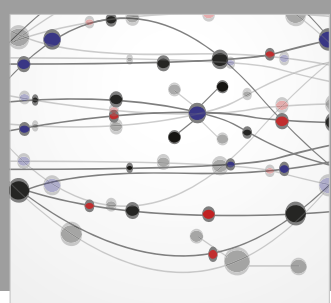

The Scientific World Journal

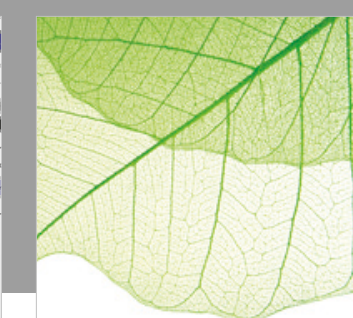

Journal of Botany

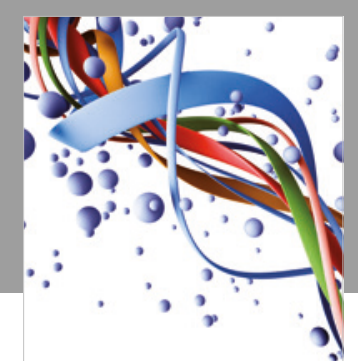

Scientifica

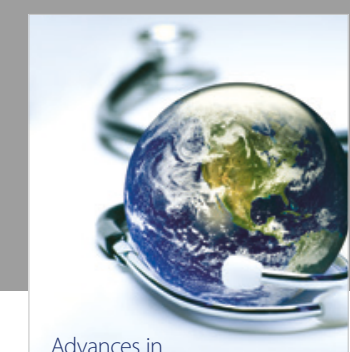

Public Health

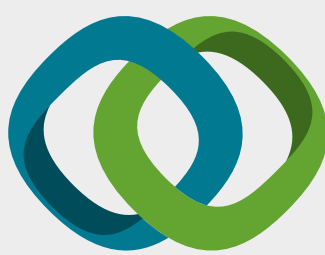

Hindawi

Submit your manuscripts at

www.hindawi.com
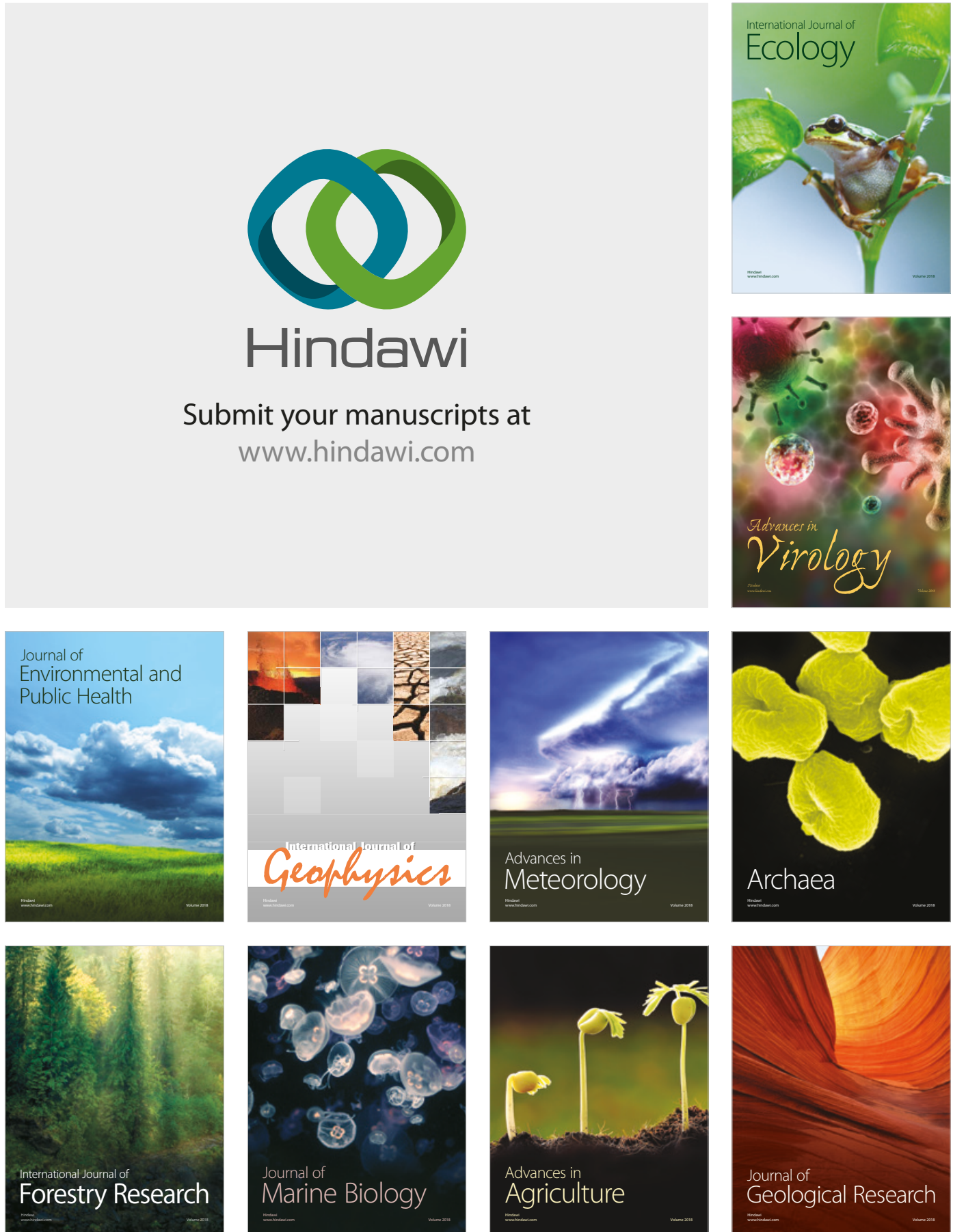

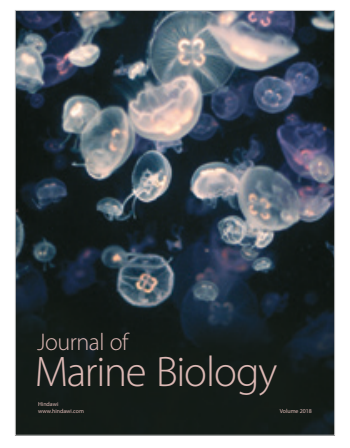

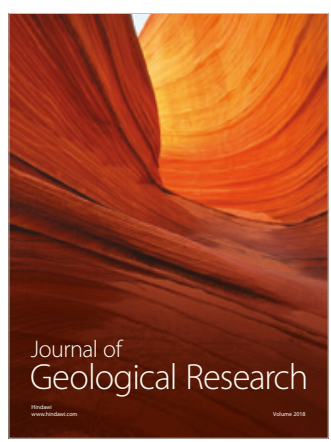

